\title{
Precarious Employment and Bargaining Power: Results of a Factorial Survey Analysis
}

\author{
Katrin Auspurg* \\ Goethe-Universität Frankfurt, Fachbereich Gesellschaftswissenschaften, Theodor-W.-Adorno-Platz 6, Postfach 29, \\ 60323 Frankfurt am Main, Germany. \\ auspurg@soz.uni-frankfurt.de
}

\section{Stefanie Gundert}

Institut für Arbeitsmarkt- und Berufsforschung (IAB), Forschungsbereich Panel "Arbeitsmarkt und soziale Sicherung" (PASS), Regensburger Str. 104, 90478 Nürnberg, Germany.

stefanie.gundert@iab.de

Summary: This article deals with the role of bargaining power in shaping workers' willingness to accept fixed-term jobs. It is assumed that workers prefer permanent contracts but may be willing to compromise on job security under certain conditions. To what extent is the willingness to accept fixed-term contracts influenced by personal characteristics and contextual factors that shape individuals' bargaining power vis-à-vis employers? In a factorial survey implemented within the German panel study "Labour Market and Social Security" (PASS) approx. 3,700 respondents evaluated more than 18,000 short descriptions (vignettes) of hypothetical job offers with an experimental variation of job characteristics, including contract type. Results show that better labor market integration and economic resources of the respondents reduce the willingness to accept insecure jobs. The effect of a better bargaining position also shows up in the higher level of financial compensation required for fixed-term contracts. Moreover, some variation by family background and gender has been found.

Keywords: Social Inequality; Labor Market; Fixed-term Contracts; Labor Supply; Bargaining Power; Experiment, Factorial Survey; PASS.

Zusammenfassung: Welche Rolle spielt die Verhandlungsmacht von Arbeitnehmern für ihre Bereitschaft, befristete Arbeitsverträge zu akzeptieren? In welchem Ausmaß ist ihre Konzessionsbereitschaft durch individuelle Merkmale oder Kontextfaktoren beeinflusst, welche die Verhandlungsmacht gegenüber Arbeitgebern bestimmen? In einem faktoriellen Survey-Modul wurden im Panel „Arbeitsmarkt und soziale Sicherung“ (PASS) im Jahr 2011 etwa 3.700 Erwerbspersonen in Deutschland zu ihrer Annahmebereitschaft hinsichtlich fiktiver Jobangebote (Vignetten) befragt, die in Merkmalen wie der Beschäftigungsdauer experimentell variiert wurden. Erwartungsgemäß reduziert eine gute Verhandlungsposition (z. B. in Form von ökonomischen Ressourcen oder einer starken Arbeitsmarktintegration) die Konzessionsbereitschaft im Hinblick auf Beschäftigungssicherheit. Der Vorteil einer solchen Position zeigt sich zudem in höheren finanziellen Kompensationen bei der Annahme befristeter Verträge. Dabei finden sich Variationen nach familiärem Hintergrund und Geschlecht.

Schlagworte: Soziale Ungleichheit; Arbeitsmarkt; Befristete Beschäftigung; Arbeitsangebot; Verhandlungsmacht; Experiment; Faktorieller Survey; PASS.

\section{Introduction}

For more than two decades high unemployment rates, increasing global competition, and economic

* The research reported in this paper was supported by a grant from the German Research Foundation (DFG; Grant Number AU394/1-1). We are grateful to Thomas Hinz, Corinna Frodermann, Christian Hohendanner, and two anonymous referees for valuable comments on an earlier draft of this paper. Part of the research was presented at the colloquium of the Collaborative Research Center (SFB) "From Heterogeneities to Inequalities" at the Bielefeld University. We thank the organizers for this opportunity and all discussants for their inspiring comments. uncertainty have been exerting pressure on Western economies to embrace greater flexibility. As a consequence of labor market de-regulation, there has been a shift from standard to non-standard employment relationships, like part-time or marginal employment, freelance work and temporary jobs in many European countries (Walwei 2013). Germany adopted several strategies of labor market de-regulation, one of which is loosening employment pro- 
tection by promoting fixed-term employment. This approach has been called a "controlled experiment" (see Regini 2000 for an example comparing Germany with other European countries), implying a reduction in employment security for part of the labour force without abandoning employment protection as a whole. Fixed-term contracts are particularly widespread among previously unemployed and low-skilled workers, but also among young graduates without work experience (Gebel \& Giesecke 2011).

Thus employment insecurity has become an even more important dimension of social inequality. First of all, fixed-term workers' wages are, on average, lower than those of permanent workers - even when differences in workers' qualifications or job characteristics are taken into account (Giesecke 2009). Moreover, fixed-term employment can have adverse health effects (Gash et. al 2007; Strandh 2000), which has been explained by the fact that unlike permanent employment temporary jobs do not fully meet basic psycho-social needs, like the opportunity for establishing social contacts, participation in collective purposes, or social status and identity (Jahoda 1981). For similar reasons insecure employment also affects workers' sense of being affiliated to society: Perceived social integration is weaker among workers in temporary than among those in permanent jobs (Gundert \& Hohendanner 2014).

This paper deals with the reasons for which workers accept unfavourable working conditions like fixed-term contracts (hereafter: FTCs). Most previous studies only focused on employers' motives for using FTCs, most notably screening or flexibilization strategies. A full understanding of the conditions under which FTCs come about requires, however, also the consideration of the worker's perspective. For instance, Breen (1997) argues that while the prevalence of standard employment in the 1970s and 1980s implied hedging against market risks and thus decommodification of large parts of the workforce, the recent increase of non-standard employment represents a shift of risks from employers to workers. The degree to which workers are affected by this process is assumed to be related to factors determining their relative bargaining position, like their social class position or the degree to which their skills are demanded. Workers with more bargaining power are expected to succeed in maintaining privileges in terms of wages and job security, which in turn reinforces their favorable bargaining position. By contrast, workers with little bargaining power bear the highest risk of employ- ment insecurity. According to this view, there are path-dependencies between different forms of social inequality. However, the prevalence of unemployment and non-standard employment also gave rise to the contrasting hypothesis of an individualization of labor market risks (Beck 1992). Proponents of this argument maintain that the relationship between social status and the distribution of risk has become loose, while individual risk factors have gained in importance.

Using the example of fixed-term jobs as one type of non-standard employment, we seek to find out to what extent current labor market inequalities are indeed shaped by power imbalances between employers and employees. So far, data restrictions rendered conclusions on the role of workers' bargaining power difficult. Most data sets contain information on accepted job offers only but not on declined ones. Thus it is impossible to determine to what extent the distribution of FTCs is mainly caused by employers' motives in making selective job offers (associated, perhaps, with the fact that FTCs are more predominant in some industries) or also by variations in workers' capacities to avoid unfavorable working conditions. Another difficulty is that even individuals with relatively high levels of bargaining power might be willing to accept FTCs, as they are at the same time better able than others to trade off job security against more favorable job attributes. Compensations for job insecurity are, however, difficult to identify in existing register and survey data.

Against this background, the present study is the first to address these issues with an experimental approach. In the large-scale German panel study PASS (see below, Section 4.2) respondents were asked to evaluate their willingness to accept hypothetical job offers described in short text vignettes with an experimental variation of job characteristics, including contract type. By carrying out a random allocation of vignettes to respondents, selection problems are overcome: All respondents, regardless of their qualification, employment history, gender or other characteristics, are presented job offers of the same quality. By focusing on workers' motives only it is possible to conclude how the willingness to accept FTCs is related to personal characteristics (like skill levels, class positions, gender) and context factors (like local unemployment rates). In addition, this design enables insights into individuals' willingness to trade off job security against other job characteristics, like monetary compensation, thus indicating in what way workers' bargaining power matters for accepting FTCs. 


\section{State of Research}

Though in Germany the share of fixed-term jobs has increased substantially over the past twenty years, it is still moderate by international comparison (OECD 2012). According to national statistics, about 9 percent of all employees held fixed-term contracts in 2010 (Wingerter 2011). However, fixed-term employment stands out with regard to its relevance in recruitment: overall, 46 percent of all newly hired workers started their jobs with FTCs in 2010 (Hohendanner 2013). At more than 60 percent the share of newly hired fixed-term workers is particularly high in the public, nonprofit and education sector, whereas in the construction and financial sector it is comparatively low (around 20 percent). As in many other countries (Addabbo \& Favaro 2012), women more often have fixed-term jobs than men. This is largely due to the fact that women are predominantly employed in sectors with comparatively high proportions of FTCs, like the education, health or nonprofit sectors (Hohendanner 2012).

Moreover, the probability of having a FTC is related to individual characteristics, such as skills and labor market experience. FTCs are concentrated among young, previously unemployed and poorly qualified workers as well as those in low-skilled jobs (Gebel \& Giesecke 2009; McGinnity et al. 2005). The incidence of FTCs is, however, also high among workers with tertiary degrees or those in high-skilled and service class positions (Gebel \& Giesecke 2009; Gundert 2007; Kurz 2002).

In attempting to find an explanation for this distribution a majority of previous studies have focused on employers' motives for offering FTCs. Employers can use FTCs for a variety of reasons that have been discussed in detail elsewhere (Gash 2008; Gebel \& Giesecke 2011; Giesecke \& Groß 2003). In a nutshell, the prevalence of FTCs is mainly explained by screening and flexibilization strategies: Given that employers are not fully aware of a job seeker's productivity they can use FTCs as screening instruments (Stiglitz 1975), which is particularly likely if jobs require high qualifications or special skills that are not or only partly signaled by a job candidate's certificates and credentials (Spence 1973). The flexibility motive, by contrast, is expected to prevail in the secondary labor market, where according to segmentation theory (Doeringer \& Piore 1971) low-skilled jobs prevail and demand shocks are typically met by numeric flexibility. If adjustment of the workforce is restricted - e. g., by strict employment protection legislation, as in the case of Germany - one way to increase flexibility is to hire fixed-term workers to circumvent dismissal costs.

Demand-side explanations, however, neglect important supply-side factors, like the job seekers' willingness to accept a job offer and their bargaining power vis-à-vis employers. With some rare exceptions, such as the case of seasonal workers (Barbieri \& Sestito 2012), it can be assumed that higher job security will be experienced as higher job quality. The opposing assumption that FTCs might be preferred seems extremely unlikely given that in Germany permanent employees have the legal right to quit their jobs at any time within a specified period of notice, whereas an early termination of a FTC requires the employers' agreement.

This raises the difficult question of why workers nonetheless accept fixed-term jobs. Unfortunately, there is a lack of reliable large-scale survey data on workers' motivations. The EU Labour Force Survey (LSF) includes questions intended to differentiate between workers who voluntarily take up fixedterm jobs (as they do not wish a permanent position) and those who accept FTCs for lack of permanent offers. Indeed, only 3 percent of all fixed-term workers in Germany do not wish a permanent position (Eichhorst et al. 2010), which is in line with the assumption that permanent jobs are, all else being equal, preferable to fixed-term jobs. However, the LFS does not allow clear conclusions on workers' motives behind accepting FTCs. In the German questionnaire there is no precise differentiation between workers' and employers' perspectives. In other countries, such as Belgium, while the questions explicitly refer to individual reasons for accepting FTCs, response categories (You can't find a suitable job and You do not want a permanent job) do not consequently juxtapose different contract types but allude to further job attributes that might have influenced the decision, like monetary compensations or career advancement. ${ }^{1}$

A plausible explanation why workers might accept FTCs even though they would prefer a permanent job might be a lack of bargaining power vis-à-vis employers (see Section 3). However, in the absence of survey data on workers' motives, drawing conclusions on the role of their bargaining power is not straightforward. At first glance, the distribution of

\footnotetext{
1 Thus it can even be questioned whether those 3 percent of "voluntary" fixed-term workers would not prefer a permanent job in case it provided the same employment conditions.
} 
FTCs is not revealing either: FTCs are concentrated among workers with weak bargaining power (such as previously unemployed and low-skilled workers) but also prominent among those in presumably favorable bargaining positions (like high-skilled individuals).

There are several explanations of those seemingly contradictory findings. First of all, the simplistic dichotomy of voluntary versus involuntary fixedterm employment needs to be called into question. Being confronted with a fixed-term offer, people do not evaluate this offer solely with respect to the temporary clause but rather consider the offer as a whole (Picchio 2012). Besides the inability to find a permanent position, concessions on job insecurity are also fostered by factors like the flexibility to reconcile employment and family, economic reasons, or the hope of using the job as a "steppingstone" into permanent employment (Tan \& Tan 2002). These motives do not indicate a preference for, but rather an instrumental attitude towards, FTCs (De Jong et al. 2009). Likewise, notwithstanding their presumed favorable bargaining position, high-skilled individuals might accept fixedterm jobs if the latter are particularly well-paid or socially valued. Indeed, the well-established finding of fixed-term workers being lower paid than permanent ones is less pronounced among high-wage workers (Mertens \& McGinnity 2005). Moreover, given that transition rates to permanent jobs are comparatively high for high-skilled workers (Baranowska et al. 2011; Gash 2008), these workers might use FTCs as stepping stones and thus trade off short-term job insecurity against long-term employment prospects.

To sum up, due to a lack of studies on workers' willingness to accept temporary jobs that are comparable to permanent jobs (apart from contract duration), there is little knowledge on the relevance of workers' bargaining power in accepting or declining insecure jobs. This lack of research is probably caused by a lack of adequate data: It is impossible to disentangle the different factors that potentially influence the decision to take up a fixed-term job with standard survey data. First of all, being a selective group with regard to characteristics like age or qualification, fixed-term workers probably also differ from permanent workers in unobservable characteristics, like ability or motivation. Consequently, it is unclear to what extent the comparatively good employment conditions among highskilled fixed-term workers represent compensations for job insecurity or rather gratifications for characteristics that justify higher rewards anyway (Ha- gen 2002). Another difficulty is that job attributes and contract type are only observable for employed individuals. Without information on declined offers neither the extent to which different workers were confronted with FTCs at all, nor trade-offs against longer job search periods can be observed. Without being able to measure all the relevant job characteristics (which is hardly possible with existing labor market data) one risks overlooking compensations for FTCs that are offered only to some privileged individuals with higher bargaining power, and thus overestimating their general willingness to accept FTCs. Ideally, a correct assessment of the conditions under which a FTC comes about requires the observation of the same individual being offered a FTC in comparison to the contrafactual situation of being offered a permanent contract with same working conditions. Below (see Section 4), some of these issues are addressed with an experimental approach.

\section{Theoretical Background: Why Do Workers Accept FTCs?}

According to human capital and job search theory (Devine \& Kiefer 1991), job searchers are rational actors seeking jobs that maximize utility. Utility is determined by monetary and non-monetary job characteristics. A job offer will be accepted if its quality (i. e. total utility) exceeds that of alternative offers. However, labor markets are characterized by frictions rendering extensive search strategies costly. In facing high information and mobility costs job seekers with few alternative options are likely to make concessions on job quality, e.g., with regard to wages or job security. Employers can take advantage of their superior bargaining position and induce workers to accept jobs that do not perfectly match their preferences; see, e. g., Manning's (2013) theory of monopsonies.

More detailed conditions can be inferred from sociological class theory. According to this perspective, an employer's interest in establishing a fixedterm employment relationship is antagonistic to the worker's interest in employment security. Which party succeeds in enforcing their interests depends on their respective bargaining power. The core concept of bargaining power can be found in different theoretical frameworks, such as social exchange or rational choice theory (Blau 1964; Emerson 1962). The bargaining power of actors in an exchange relationship hinges on their dependency on the relationship, and this dependency varies with the availability of alternative options. Hence, the more 
alternative (job) options an individual has, the less she or he is compelled to accept unfavorable bargaining solutions (e. g., unfavorable working conditions). In his class theory, Wright (1997) assumes that a worker's relative bargaining position hinges on two aspects: skills and authority. High-skilled workers with highly demanded qualifications are assumed to be in privileged positions that allow them to refuse unfavorable job conditions because of their good chances of finding more attractive jobs. Hence it can be assumed that:

H1: High-skilled individuals are less willing to accept fixed-term jobs than low-skilled individuals.

Likewise, individuals who apply for executive positions with high levels of authority and job discretion are expected to be in positions of relative power as their performance is hard to monitor by employers. In anticipation of potential disincentive effects, employers usually refrain from filling those positions with fixed-term employees but rather grant employment security and promotion opportunities to ensure loyalty among employees. Such arrangements are characteristic of service relationships (Erikson \& Goldthorpe 1992). Breen (1997) expects employment security to be an essential aspect of high-skilled service class positions. Assuming that they are aware of their advantageous bargaining position, it can be hypothesized that:

H2: Upper service class employees are less willing to accept FTCs than employees and workers in other class positions. $^{2}$

Apart from that, it seems reasonable to expect path dependencies between current and future employment status. Compared to employed individuals, the bargaining position of unemployed individuals is weaker. Their job opportunities are likely reduced due to human capital depreciation or stigmatization. Besides, unemployment can involve economic pressure to take up any job, irrespective of its long-term perspective. As for employed individuals, their willingness to accept alternative job offers will be affected by the quality of their current jobs, notably the contract type. For workers who

\footnotetext{
2 According to Wright and Goldthorpe class and skills (or, respectively, authority) are closely related. The class of employees is structured along these two dimensions, with members of the service classes showing both high skills and authority. Yet individual skills can be expected also to have an independent effect on bargaining power. EGP classes are defined by occupational skill levels - which are closely related but do not necessarily perfectly correspond to individual skills. Moreover, skills can be assumed to also affect the bargaining power of unemployed individuals who are not captured by the EGP scheme.
}

already have a permanent job, fixed-term job offers should appear less attractive than permanent ones. By contrast, having a temporary job exerts more pressure to accept even short-term offers. Hence one would expect path dependencies regarding the type of employment:

H3a: Unemployed individuals are more willing to accept FTCs than employed individuals.

H3b: Employees holding permanent contracts are less willing to accept FTCs than those holding fixed-term or temporary agency contracts.

Apart from that, the pressure to accept any job can be expected to hinge on the availability of financial resources that are reflected in the total disposable household income (including earnings and social benefits). The better individuals are shielded from market risks by such decommodifying financial resources, the better they will be able to decline insecure job offers:

H4: The willingness to accept FTCs decreases with the level of household income.

The power relations between employers and employees are linked to the balance of demand and supply of labor. High local unemployment rates might exert pressure on individuals to accept jobs in avoiding the high costs of migrating to regions with better employment prospects. Furthermore, given that seeking work in other industrial sectors is often not a viable strategy in highly-standardized occupational labor markets, workers' capacity to avoid insecure employment is also likely to be affected by conditions in the particular sector they are currently employed in. It can be expected that the chances of receiving a permanent job in a certain industry sector are contingent on the sectorspecific prevalence of fixed-term employment. ${ }^{3}$ Sectors differ in their average shares of FTCs for reasons such as: sector-specific incentives for employers to use FTCs (like the flexibility motive); different levels of collective bargaining power among workers resulting from differences in union density or other forms of worker representations (Holst 2014); or different degrees of monopsonistic power on the part of employers. ${ }^{4}$ In any case, a high con-

${ }^{3}$ For instance, there is evidence for Spain (Ortiz 2010) that the higher the overall incidence of FTCs, the lower workers' chances to find permanent jobs. Similarly, in Germany some of the sectors with the highest share of newly hired fixed-term workers (public and non-profit services and education) are at the same time characterized by below-average rates of conversions into permanent contracts (Hohendanner 2013).

${ }^{4}$ In some sectors characterised by state monopolies (nota- 
centration of fixed-term employment reduces the chance of receiving a permanent job. In this context, employers have monopsonistic power to enforce unfavorable employment conditions. In sum, we expect that:

H5a: The higher the regional unemployment rate, the higher is the individual willingness to accept FTCs.

H5b: Workers' acceptance of fixed-term job offers is higher if they are working in industrial sectors with high shares of FTCs.

\section{Exploring the Impact of Gender and Family Background}

Even though neglected by most prior research, gender and family context seem additionally important. While on the aggregate level the risk of having a FTC is similar for men and women when accounting for the fact that women are frequently employed in sectors with particularly high proportions of FTCs, there are still noteworthy gender differences with respect to specific positions. For example, women in high-skilled executive positions have a somewhat higher risk than men to have a FTC (Kurz 2002). Whether these FTCs are disadvantageous for women remains an unresolved issue: again, answering that question would require controlling all possible compensations for the limited contract duration, like higher wages or better career chances, which is hardly possible; and there is even less knowledge on how family obligations intervene with (gender-specific) risks of holding FTCs. $^{5}$

From a theoretical perspective, the willingness to make concessions regarding job security should hinge on decommodifying living conditions. Having a partner who is active in the labor market can facilitate the decision to reject a fixed-term job offer. In contrast, having no or an unemployed partner should increase the economic pressure to take up any job. Furthermore, family ties constrain individuals' geographic mobility (choices of residence and commuting distances). Restricted mobility implies limited access to suitable job offers (Mincer 1978). According to bargaining theory, restricted access to alternative job offers on the part of work-

bly health, education, and science) the use of FTCs is mandatory for entry positions and the FTC rate therefore high. Institutionalized fixed-term job periods are, for instance, an integral part of training for prospective teachers and doctors. Moreover, entry positions for academic researchers and lecturers are generally non-tenured in Germany.

${ }^{5}$ For instance, Kurz (2002) only looked at entry-cohorts that typically do not have started a family yet. ers provides employers monopsonistic power to enforce less favorable employment conditions (Manning 2003). Both processes are likely to be moderated by gender. Women more likely than men have partners with higher earning power (Blossfeld et al. 2001), i. e., they are more likely to benefit from decommodifying living conditions. However, exactly this aspect makes them also more tied to specific geographic locations, implying a lower bargaining power to decline inferior job conditions (Auspurg \& Schönholzer 2013).

At the current state of research, it is difficult to estimate the prevalence of the different mechanisms. Therefore we will explore the interplay of family status and gender without specifying any distinct hypotheses.

\section{Method and Data}

\subsection{Experimental Design}

To overcome the empirical problems sketched in the former sections, an experimental factorial survey method (Jasso 2006; Rossi \& Anderson 1982; Wallander 2009) is used. Respondents in a largescale population survey were asked to evaluate five hypothetical job offers (vignettes) composed of eight experimentally varied dimensions like gain of income, career prospects, commuting time and most importantly - contract type. About one third of the offers were described as being based on a FTC limited to one year, one third were indicated to be limited to three years, and the remaining one third as being based on a permanent contract. The dimensions and levels were defined by factors that are well known to have an impact on labor market inequalities and, at the same time, on decisions to take up (new) jobs. ${ }^{6}$ When selecting the levels it was taken care of choosing only those levels that combine to plausible vignettes and cause sufficient variation in attractiveness and hence respondents' willingness to accept an offer. Moreover, the number of levels was carefully chosen to be balanced and as small as possible (yielding a high statistical power to identify causal relationships; Auspurg \& Hinz 2015) but still sufficient for an estimation of non-linear relations of the dependent variable and vignette dimensions: All dimensions were composed of three levels; only for the income dimension more levels (5) were specified. Respondents rated

\footnotetext{
${ }^{6}$ For results produced with a similar factorial survey module see Abraham et al. 2010.
} 
their likelihood to accept the offers using an 11point rating scale. ${ }^{7}$ The following example illustrates the structure of vignettes (varied dimensions ${ }^{8}$ in italics). The income in case of accepting the job represented the actual income of respondents' household plus an experimentally varied percentage increase (ranging from 0 up to $80 \%$ ), rounded to 100 euros. $^{9}$

If you accept the offered job, your net household income will rise to 3,500 euros.

The working hours are 20 hours per week, and the job requirements are significantly below your professional skills.

The job offers many opportunities for internal promotion and is limited to 3 years.

The one-way trip from your current place of residence to the location of the job is approximately 6 hours.

The labor market at the new location is worse than at your current residence.

Finding appropriate housing there will require considerable effort.

How likely would you accept this offer? Respondents were asked to report on an 11-point scale, reaching from 0 ("very unlikely") to 10 ("very likely").

A total of 500 different vignettes were constructed following the high standards of multi-factorial experimental designs (Abraham et al. 2013; Frodermann et al. 2013). Thereby correlations between the different dimensions are minimized, which allows to estimate their impact with maximum precision. ${ }^{10}$ By carrying out a random allocation of vignettes to respondents it was possible to overcome selection problems: all respondents, regardless of their qualification, labor market history, gender or

\footnotetext{
${ }^{7}$ In addition, all respondents were asked to rate the attractiveness of the offer and the likelihood that they would move to the new location.

8 The varied dimensions and levels were: (1) Gain of household income (five levels from 0 to $80 \%$ ); (2) working hours (20/30/40 hours); (3) job requirements (not/ slightly/significantly below professional skills); (4) opportunities for internal promotion (none/few/many); (5) contract type (permanent/1-year/3-year FTC); (6) commuting time (1/4/6 hours); labor market at new location (worse/ similar/better); (7) effort needed to find appropriate housing (low/some/high).

9 For example, if the actual household income was 2,490 euros and the vignette level was an increase of 20 percent, the text would read: "By accepting the offer your household income will rise to 3,000 euros".

${ }^{10}$ In the vignette sample all correlations between vignette dimensions were close to zero $(|r|<0.04)$.
}

other characteristics, were presented job offers with the same distribution of characteristics and also the same proportions of fixed-term versus permanent contracts. Moreover, as each respondent evaluated several offers, it is possible to observe how the same respondent reacts when confronted with a fixed-term instead of permanent offer.

Thorough analyses revealed the experimental stimuli (job offer dimensions) to be balanced in terms of socio-demographic characteristics of respondents. Thus, the random allocation of stimuli to respondents was successfully implemented (see Table A2.3 in the online appendix to this article): ${ }^{11}$ all bivariate correlations between respondent characteristics and the vignette dimension indicating the contract type are close to zero $(|r|<0.025)$; these very low correlations indicate a successful randomization (for further randomization checks see the online appendix). Moreover, the realized sample was highly balanced in terms of the levels of the different experimental treatments - all kinds of contracts occur with about the same frequency. For descriptive information see Tables A2.1 and A2.2 in the online appendix.

\subsection{Respondent Sample}

The experiment was included in the fifth wave (surveyed in 2011) of the panel study Labour Market and Social Security (PASS), which is conducted annually by the Institute for Employment Research (IAB). PASS is designed for research on the labor market and poverty in Germany (Trappmann et al. 2013). The total sample is a combination of two subsamples, one of which is drawn from the unemployment registers of the Federal Employment Agency, while the second is a general population sample, oversampling low-status households. For observing the causal impact of experimental factors (like contract type) individuals do not have to represent a random sample. Instead, the random allocation of treatments is essential (Mutz 2011). ${ }^{12}$

The experiment was conducted by computer-assisted personal interviews (CAPI) of individuals who were available to the labor market. Besides respondents with missing values on core variables re-

\footnotetext{
11 www.zfs-online.org

12 To provide plausible and meaningful vignette stimuli to all respondents, including those in low-income households, the dimension 'gain of household income' was tailored to respondents' specific household income (also see Table A2.2 in the online appendix and Frodermann et al. 2013).
} 
spondents not interested in paid work (like housewives) and self-employed persons were excluded from the analyses.

A total of 18,366 evaluations made by 3,698 respondents are used for multivariate data analyses. Table A2.1 (online appendix) gives an overview of the sample, demonstrating a high level of variation regarding core respondent variables, like education or class position.

Respondents' educational level was assessed on the basis of the CASMIN classification combining information on the highest school as well as vocational degree (Brauns et al. 2003). In the analysis the focus is on occupational qualification. Therefore the categories were aggregated to three groups: CASMIN_low (reference category) includes individuals without any vocational or tertiary qualification (summarizing categories " $1 \mathrm{a}$ ", " $1 \mathrm{~b}$ ", " $2 \mathrm{~b}$ " and "2c, gen”); CASMIN_medium refers to individuals who completed vocational training (" $1 \mathrm{c}$ ", " $2 \mathrm{a}$ " and " $2 c$, voc"); CASMIN_high refers to those with tertiary education (" $3 \mathrm{a}$ " and " $3 \mathrm{~b}$ "). Employment status was captured by three categories: permanent workers (reference category), a combined category of workers with FTCs and temporary agency workers $(\mathrm{TAWs})^{13}$, and unemployed individuals.

For employed persons, their occupational class position was measured with an aggregated version of the Erikson-Goldthorpe-Portocarero (EGP) class scheme (Erikson \& Goldthorpe 1992), resulting in six categories, of which the upper service class (class I: higher grade professionals) is chosen as reference category.

To account for context factors the local unemployment rate and industry-specific share of FTCs are included in the analyses. ${ }^{14}$ To map respondents' household context, an indicator of the presence and employment status of cohabiting partners was created. Individuals without partners (reference cate-

13 Given the low number of agency workers $(n=141)$ collapsing the categories ensures a sufficient number of cases. The impact of either fixed-term or temporary agency jobs on employment decisions is expected to be very similar, as compared to permanent jobs both types of employment are associated with lower levels of job security and wages. 14 The unemployment rate was gathered from register data of the Federal Employment Agency and refers to 418 administrative districts comprising cities and rural districts. The degree to which FTCs are common for new hires in a specific industry was measured by the percentage of fixed-term workers among all newly hired workers in that industry, based on information from the IAB Establishment Panel on 19 aggregated groups of industries (Hohendanner 2013).

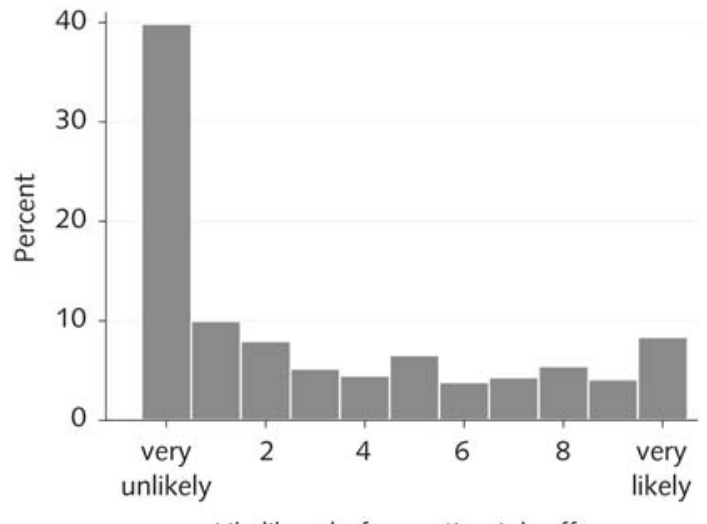

Likelihood of accepting job offer

Note: $n=3,698$ respondents and $n=18,366$ evaluations

Fig. 1 Distribution of Responses - Willingness to Accept a Job Offer

gory) are distinguished from those living with employed or unemployed partners.

\subsection{Descriptive Results}

Figure 1 shows the distribution of the dependent variable, i. e., the willingness to accept a job offer. There were only 2.2 percent missing values. The strong clustering of evaluations on the category very unlikely fits well to the generally low willingness to move among German workers (about two thirds of the offers were characterized as being outside a daily commuting distance of one hour). ${ }^{15}$ The response pattern is also in line with multistage decision processes where only in case of a principal interest in new options the specific conditions are evaluated in detail (Abraham et al. 2013).

\subsection{Regression Techniques}

In accordance with other work on labor supply, the double hurdle approach of the "craggit model" (Cragg 1971) is used. It allows formulating two separate processes underlying a limited outcome like the vignette evaluations on our 11-point rating scale. On the first stage (tier 1) a probit model is used to estimate whether an individual is poten-

\footnotetext{
15 Additional analyses revealed results to be very similar for job offers within daily commuting distance (one hour) and for offers beyond this distance (four or six hours driving distance). Therefore pooled analyses on all job offers are reported.
} 
tially willing to accept the job offer (i.e., the dependent variable exceeds zero). On the second stage (tier 2), a truncated linear regression model is estimated (addressing the truncation resulting from $y>$ $0)$. Here, the degree to which an offer is accepted is modeled (Wooldridge 2010). For coefficients included on both tiers maximum likelihood estimates indicate their effects on each tier separately. In addition, average partial effects (APEs) are estimated that summarize the effects of both tiers and represent the overall effect each variable has on the reported likelihood to accept an offer (more details on the craggit model in the online appendix). Personal traits, such as age, family status and all characteristics reflecting individuals' bargaining power are assumed to affect both the principal decision on the first tier as well as the fine-tuning on the second stage. Similarly, commuting distance and contract type can be expected to have a meaningful impact on both decision stages.

For tier 2, job characteristics that seem of subordinated importance (like promotion prospects) are added. Both models include the same list of control variables (see bottom of the results tables). All hypotheses are tested in the form of interaction effects: Are the (expected) negative effects of FTCs on the willingness to accept job offers particularly strong for subgroups that are assumed to have a relatively high bargaining power? Cluster-robust standard errors (Rogers 1993) are used to adjust for unequal variances of error terms (heteroscedasticity). The latter result from the clustering of observations as each respondent evaluated several job offers (more details on this in the online appendix). In all models, regional contexts are controlled in the form of regional unemployment rates (hence no additional clusters for regional units were estimated). In the online appendix we provide extensive checks of the robustness of results with respect to alternative statistical models that could fit the data structure (Table A2.4 and Figure A2.1).

\section{Results}

\subsection{Impact of Contract Type}

The contract type has substantial impact on the reported likelihood of accepting a job offer: The mean evaluation of 1 -year contracts is 2.60 , which is significantly closer to the rating "very unlikely" than the mean evaluation of 3-year and permanent contracts (which are 3.07 and 3.59 respectively (a test of the analysis of variance (ANOVA) yields $F$
$(2 ; 18363)=123.2 ; p=0.000)$. This finding supports the basic assumption that FTCs are experienced as unfavorable working conditions.

\subsection{Conditions Favoring the Acceptance of FTCs}

The hypotheses are tested by applying the craggit model (Table 1). Besides control variables, the base model (Model I) contains six vignette variables including the type of contract - along with variables relevant for testing the hypotheses (like educational level). Regarding the vignette variables, all coefficients can be interpreted in a plausible way. The gain of household income is positively related to both respondents' principal decision of considering an offer at all (tier 1 , first line: $\beta=0.07$ ), and if so, the fine-grained evaluation of their propensity to accept it (tier 2: $\beta=0.35$ ). To facilitate interpretation, a third column displays average partial effects (APEs) that summarize the effects of both tiers on the dependent variable. ${ }^{16}$ The APE of 0.256 in the first line means, for instance, that, if the gain of household income rises by 10 percent, the reported likelihood of accepting the offer will increase, on average, by about 0.256 points on the 11 -point rating scale.

Likewise, the more hours individuals would have to work for a given gain of household income, the lower their willingness to accept an offer will be. ${ }^{17}$ Strong negative and highly significant effects are observed for FTCs in particular, which corroborates the descriptive results: all else being equal, jobs are perceived to be more attractive if the duration of the contract is longer.

At the bottom of Table 1, effects of the education variables are displayed; all have negative (yet not significant) APEs. The right-hand side of Table 1 shows the model (Model II) for testing the first hypothesis that high-skilled individuals would be less willing to accept FTCs. The base model is enlarged by four interaction terms of the upper two levels of education (CASMIN_medium or CASMIN_high) with the two different FTC offers (3-year or 1-year contract). While all APEs display the expected

\footnotetext{
${ }^{16}$ For APEs standard errors were estimated using bootstrap procedures (Burke 2009) with 100 replications and the Stata ado craggit (see online appendix).

17 This is a plausible result given that the effect of working hours, like all effects, was estimated under control of all other vignette dimensions, including 'gain of household income'. Hence, a higher amount of working hours given a specific gain of household income implies a lower hourly wage.
} 
Table 1 Craggit Models of Willingness to Accept a Job Offer (Regression Coefficients and APEs)

\begin{tabular}{|c|c|c|c|c|c|c|}
\hline & \multicolumn{3}{|c|}{ Model I } & \multicolumn{3}{|c|}{ Model II } \\
\hline & Tier 1 & Tier 2 & APEs & Tier 1 & Tier 2 & APEs \\
\hline Gain of household income [10 \%] & $\begin{array}{c}0.0681^{* * *} \\
(0.00453)\end{array}$ & $\begin{array}{l}0.352^{* * *} \\
(0.0220)\end{array}$ & $\begin{array}{l}0.256^{* * *} \\
(0.0104)\end{array}$ & $\begin{array}{c}0.0683^{* * *} \\
(0.00453)\end{array}$ & $\begin{array}{l}0.353^{* * *} \\
(0.0220)\end{array}$ & $\begin{array}{c}0.257^{* * *} \\
(0.0105)\end{array}$ \\
\hline \multicolumn{7}{|l|}{ Working hours (ref.: 20 hours) } \\
\hline 30 hours & & $\begin{array}{c}-0.43 * * \\
(0.125)\end{array}$ & $\begin{array}{c}-0.178 * * \\
(0.0528)\end{array}$ & & $\begin{array}{l}-0.434 * * \\
(0.125)\end{array}$ & $\begin{array}{c}-0.178 * * \\
(0.0530)\end{array}$ \\
\hline 40 hours & & $\begin{array}{l}-0.801^{* * *} \\
(0.121)\end{array}$ & $\begin{array}{l}-0.328^{* * *} \\
(0.0465)\end{array}$ & & $\begin{array}{l}-0.801^{* * *} \\
(0.121)\end{array}$ & $\begin{array}{l}-0.328^{* * *} \\
(0.0466)\end{array}$ \\
\hline \multicolumn{7}{|l|}{ Over-qualification (ref.: none) } \\
\hline Slight & & $\begin{array}{l}-0.155 \\
(0.0976)\end{array}$ & $\begin{array}{r}-0.0635^{+} \\
(0.0358)\end{array}$ & & $\begin{array}{l}-0.157 \\
(0.0973)\end{array}$ & $\begin{array}{r}-0.0642^{+} \\
(0.0358)\end{array}$ \\
\hline Considerable & & $\begin{array}{l}-0.244^{*} \\
(0.0993)\end{array}$ & $\begin{array}{l}-0.100^{*} \\
(0.0410)\end{array}$ & & $\begin{array}{l}-0.247^{*} \\
(0.0992)\end{array}$ & $\begin{array}{l}-0.101 * \\
(0.0413)\end{array}$ \\
\hline \multicolumn{7}{|l|}{ Prospects of promotion (ref.: none) } \\
\hline Few & & $\begin{array}{c}0.0220 \\
(0.102)\end{array}$ & $\begin{array}{c}0.00903 \\
(0.0434)\end{array}$ & & $\begin{array}{c}0.0249 \\
(0.102)\end{array}$ & $\begin{array}{c}0.0102 \\
(0.0431)\end{array}$ \\
\hline Many & & $\begin{array}{l}0.512^{* * *} \\
(0.1000)\end{array}$ & $\begin{array}{l}0.210^{* * *} \\
(0.0389)\end{array}$ & & $\begin{array}{l}0.513^{* * *} \\
(0.1000)\end{array}$ & $\begin{array}{l}0.210^{* * * *} \\
(0.0388)\end{array}$ \\
\hline \multicolumn{7}{|l|}{ Commuting distance (ref.: 1 hour) } \\
\hline 4 hours & $\begin{array}{l}-0.607^{* * *} \\
(0.0270)\end{array}$ & $\begin{array}{l}-2.636^{* * *} \\
(0.113)\end{array}$ & $\begin{array}{l}-2.078 * * * \\
(0.0697)\end{array}$ & $\begin{array}{l}-0.607^{* * *} \\
(0.0270)\end{array}$ & $\begin{array}{l}-2.635^{* * *} \\
(0.113)\end{array}$ & $\begin{array}{l}-2.077^{* * *} \\
(0.0700)\end{array}$ \\
\hline 6 hours & $\begin{array}{l}-0.810^{* * *} \\
(0.0279)\end{array}$ & $\begin{array}{l}-2.637^{* * *} \\
(0.119)\end{array}$ & $\begin{array}{l}-2.413^{* * *} \\
(0.0654)\end{array}$ & $\begin{array}{l}-0.810 * * * \\
(0.0279)\end{array}$ & $\begin{array}{l}-2.636^{* * *} \\
(0.119)\end{array}$ & $\begin{array}{l}-2.412^{* * *} \\
(0.0656)\end{array}$ \\
\hline \multicolumn{7}{|l|}{ FTC (ref.: permanent contract) } \\
\hline 3-year contract & $\begin{array}{l}-0.130 * * * \\
(0.0242)\end{array}$ & $\begin{array}{l}-0.800 * * * \\
(0.0984)\end{array}$ & $\begin{array}{l}-0.542 * * * \\
(0.0586)\end{array}$ & $\begin{array}{c}-0.140 * * \\
(0.0460)\end{array}$ & $\begin{array}{l}-0.562 * * \\
(0.180)\end{array}$ & $\begin{array}{l}-0.461 * * * \\
(0.106)\end{array}$ \\
\hline 1-year contract & $\begin{array}{l}-0.271^{* * *} \\
(0.0251)\end{array}$ & $\begin{array}{l}-1.262^{* * *} \\
(0.107)\end{array}$ & $\begin{array}{l}-0.963 * * * \\
(0.0581)\end{array}$ & $\begin{array}{l}-0.244^{* * *} \\
(0.0488)\end{array}$ & $\begin{array}{l}-1.055^{* * *} \\
(0.195)\end{array}$ & $\begin{array}{c}-0.833^{* * *} \\
(0.108)\end{array}$ \\
\hline \multicolumn{7}{|l|}{ Education (ref.: CASMIN_low) } \\
\hline CASMIN_medium & $\begin{array}{c}0.00138 \\
(0.0399)\end{array}$ & $\begin{array}{c}-0.282^{+} \\
(0.154)\end{array}$ & $\begin{array}{l}-0.113 \\
(0.0999)\end{array}$ & $\begin{array}{c}-0.00435 \\
(0.0515)\end{array}$ & $\begin{array}{c}-0.0882 \\
(0.187)\end{array}$ & $\begin{array}{c}-0.0433 \\
(0.124)\end{array}$ \\
\hline CASMIN_high & $\begin{array}{c}0.0563 \\
(0.0631)\end{array}$ & $\begin{array}{l}-0.299 \\
(0.244)\end{array}$ & $\begin{array}{c}-0.0300 \\
(0.153)\end{array}$ & $\begin{array}{c}0.150^{+} \\
(0.0829)\end{array}$ & $\begin{array}{c}-0.0962 \\
(0.283)\end{array}$ & $\begin{array}{c}0.207 \\
(0.198)\end{array}$ \\
\hline \multicolumn{7}{|l|}{ Education X FTC: } \\
\hline CASMIN_med. X 3-year contract & & & & $\begin{array}{c}0.0240 \\
(0.0553)\end{array}$ & $\begin{array}{c}-0.382+ \\
(0.220)\end{array}$ & $\begin{array}{l}-0.117 \\
(0.129)\end{array}$ \\
\hline CASMIN_med. X 1-year contract & & & & $\begin{array}{l}-0.00597 \\
(0.0582)\end{array}$ & $\begin{array}{c}-0.239 \\
(0.238)\end{array}$ & $\begin{array}{c}-0.108 \\
(0.142)\end{array}$ \\
\hline CASMIN_high X 3-year contract & & & & $\begin{array}{c}-0.0513 \\
(0.0888)\end{array}$ & $\begin{array}{l}-0.104 \\
(0.343)\end{array}$ & $\begin{array}{l}-0.127 \\
(0.214)\end{array}$ \\
\hline CASMIN_high X 1-year contract & & & & $\begin{array}{l}-0.222 * \\
(0.0893) \\
\end{array}$ & $\begin{array}{c}-0.644 \\
(0.399) \\
\end{array}$ & $\begin{array}{l}-0.629 * * \\
(0.214)\end{array}$ \\
\hline Constant & $\begin{array}{l}1.343^{* * *} \\
(0.302)\end{array}$ & $\begin{array}{l}4.407^{* * *} \\
(1.248)\end{array}$ & & $\begin{array}{l}1.337^{* * *} \\
(0.303)\end{array}$ & $\begin{array}{c}4.252^{* *} \\
(1.252)\end{array}$ & \\
\hline$\sigma$ & $\begin{array}{r}3.53 \\
(0.03\end{array}$ & $\begin{array}{l}31 * * * \\
388)\end{array}$ & & & $\begin{array}{l}30 * * * \\
388)\end{array}$ & \\
\hline $\begin{array}{l}n \text { Vignettes } \\
n \text { Respondents }\end{array}$ & & $\begin{array}{c}18,366 \\
3,698\end{array}$ & & & $\begin{array}{c}18,366 \\
3,698\end{array}$ & \\
\hline
\end{tabular}

Note: Additional control variables of experimental dimensions: local employment opportunities, effort needed to find appropriate housing. Control variables for respondents' characteristics: sex, age, employment status, net household income, migration background, local unemployment rate, property ownership, children in household, attachment to place of residency, community size, East/West Germany. ${ }^{* *} \mathrm{p}<0.001,{ }^{*} \mathrm{p}<0.01,{ }^{*} \mathrm{p}<0.05 ;{ }^{+} \mathrm{p}<0.1$. 
a) Education

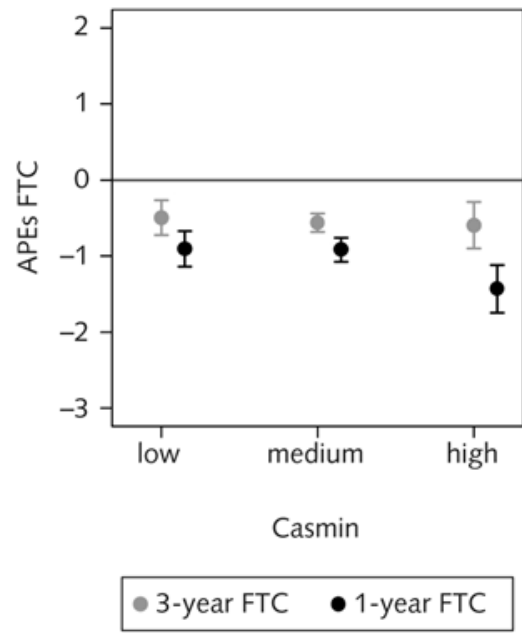

b) Employment Status

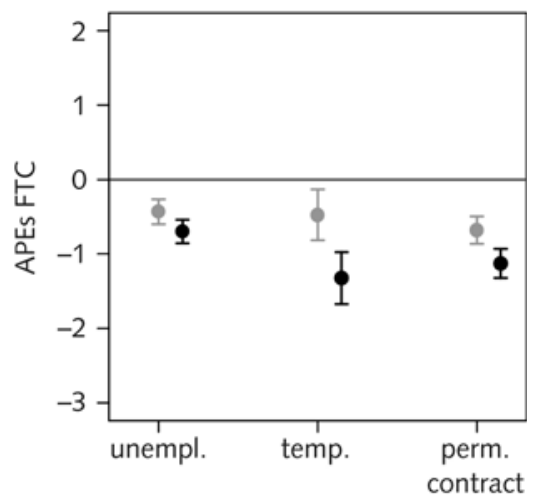

Employment Status

Note: APEs from craggit models estimated separately for respondents with different educational level or employment status. All estimates are based on at least $n=1,900$ evaluations of job offers.

Fig. 2 APEs of FTCs by Education and Employment Status with $95 \% \mathrm{Cls}$

negative signs, only the last one (the interaction of CASMIN_high and a 1-year contract) is statistically significant: compared to respondents with elementary education, those with tertiary education rated their propensity of accepting a 1-year contract considerably lower.

In a similar vein, further models for the remaining hypotheses were estimated. For ease of interpretation, graphical illustrations are displayed in Figures 2 a to 3 (for the exact results, based on pooled estimations like the ones shown in Table 1 , see Table 2 below). Figure 2a illustrates the interaction of contract type with educational level as shown in Table 1. Point estimates and 95\%-confidence intervals (CIs) for the APEs of a 3-year (grey symbols) and 1 -year contract (black symbols) are plotted. APEs result from separate estimations of the base model for the three educational groups. In all groups permanent contracts are significantly preferred over FTCs: all effects are negative with the $95 \%$-CIs not overlapping with the zero line. Comparing effects across educational groups, the only statistically significant difference refers to individuals with tertiary degrees (CASMIN_high) being less willing to accept 1-year contracts than those with lower levels of education (CIs do not overlap; see also Table 2 for significance levels when estimating a pooled model like the one shown in Table 1). ${ }^{18}$

18 The figures (showing FTC effects estimated separately
Figure $2 \mathrm{~b}$ illustrates the results for employment status. In line with hypothesis $\mathrm{H} 3 \mathrm{a}$, individuals who were employed at the time of the survey are more likely than unemployed individuals to decline a 1year contract. However, permanent and temporary workers do not differ significantly in their willingness to accept FTCs. This does not support the assumption of permanent workers being in a better position to reject FTCs than those with temporary contracts (hypothesis $\mathrm{H} 3 \mathrm{~b}$ ).

In Figure 3, effects for occupational class positions are plotted. Again, the finding that respondents generally prefer permanent contracts over FTCs clearly supports our basic assumption of FTCs representing unfavorable working conditions. There is one significant difference across class positions: in line with hypothesis $\mathrm{H} 2$ upper service class workers are less willing to accept 1 -year contracts than individuals from all other classes.

No evidence, however, is found (and hence no graphs are presented) for the supposed positive ef-

for the different respondent groups) offer a better illustration of group differences than the pooled estimates with interaction terms in the tables. However, due to the higher number of cases, the pooled estimates provide somewhat more power to detect group differences. In some cases of borderline statistical significance the group differences in the tables might be found to be statistically significant although the CIs in the figures marginally overlap. 


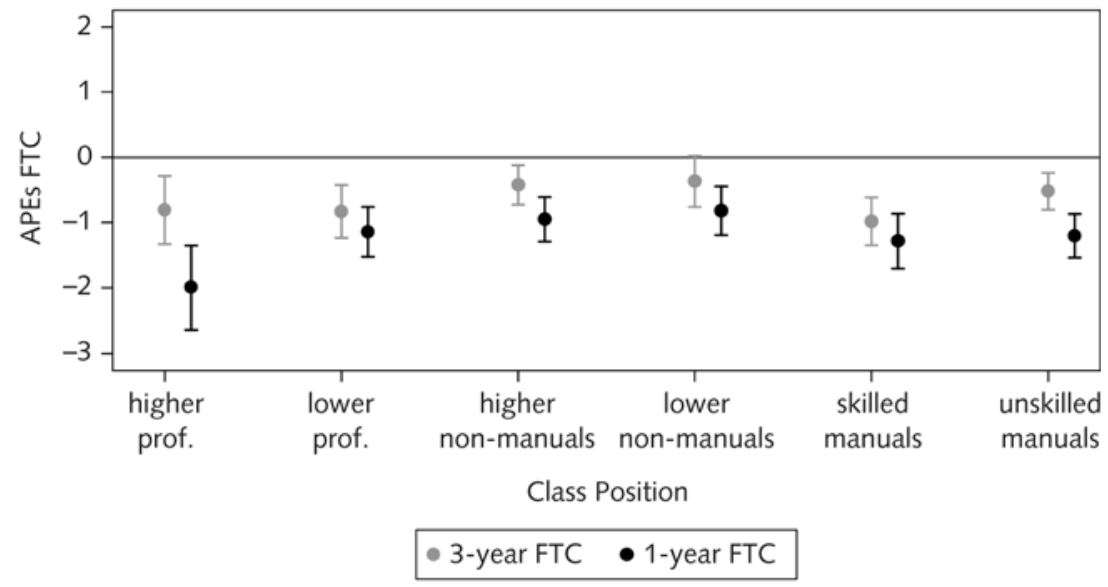

Note: APEs from craggit models estimated separately for respondents with different occupational class positions. All estimates are based on at least $n=724$ evaluations of job offers.

Fig. 3 APEs of FTCs by EGP with $95 \% \mathrm{Cls}$

fects of the local unemployment rate and industryspecific share of FTCs (with regard to new hires). ${ }^{19}$ Only for the local unemployment rate APEs show the expected positive sign, but none is statistically significant. Based on the data at hand, the respective hypotheses $(\mathrm{H} 5 \mathrm{a} / \mathrm{b})$ have to be rejected.

Table 2 finally summarizes APEs for all interaction terms of FTCs with the variables related to hypotheses. For single hypotheses comprising several interaction effects, the table provides a summary $\mathrm{Chi}^{2}{ }^{-}$ test for their joint significance; thus Table 2 offers a compact overview on the impact of all different factors. ${ }^{20}$ The description is confined to effects of the 1 -year condition, which are in each case similar to (albeit somewhat stronger than) effects of the 3-year condition. These tests again support the expectation that individuals with higher education, permanent jobs or upper service class positions are more likely to decline FTCs than other individuals. Besides, there is evidence for a decommodifying effect of financial resources (H4): net of their educational and employment status, individuals with higher household income are less prone to accept FTCs.

Finally, at the bottom of the table, effects for gender and family status are reported. Female respondents

\footnotetext{
19 Similar results are obtained by using a more general measure, i. e. the total industry-specific share of FTCs.

${ }^{20}$ Moreover, as already mentioned, the pooled estimates shown in Tables 1 and 2 offer a little more statistical power than the estimates displayed in the figures (that were run separately for different groups of respondents).
}

tend to display a higher willingness to accept FTCs. Compared to being single living with an employed partner reduces the propensity to accept a FTC but only for men. For women there is no significant variation by family status. The interplay of family status and gender can also be observed in Figure 4, where again APEs offer an illustration of the group comparisons. The non-existing effect of family status among women might be caused by different causal mechanisms cancelling each other out. We get back on this issue in the discussion.

\subsection{Monetary Compensations}

The experimental design also allows estimating the amount of monetary compensation that would have to be offered so that fixed-term contracts are as likely to be accepted as permanent ones. Those measures of "willingness to pay" for favorable conditions (or, respectively, "willingness to avoid" unfavorable conditions) offer even more detailed insights into effect sizes of attributes (like jobs being temporary or not). They are frequently used in economics in combination with choice experiments but can also be applied to factorial surveys. Their rare use in sociology probably reflects researchers' unawareness of these measures (Auspurg \& Hinz 2015).

Technically, information on monetary compensations is gained by the cross-elasticity of the contract type and the monetary dimension that is repre- 
Table 2 Craggit Estimates: Interactions of 1-Year FTC with Respondents' Characteristics

\begin{tabular}{|c|c|c|c|}
\hline & APE & Chi $^{2}-$ Test $^{\mathrm{a}}(\mathrm{df})$ & $\begin{array}{l}n \text { evaluations } \\
\text { (respondents) }\end{array}$ \\
\hline \multicolumn{4}{|l|}{ Education (ref.: CASMIN_low) } \\
\hline CASMIN_medium & -0.108 & $9.83 *$ & 18,366 \\
\hline CASMIN_high & $-0.629 * *$ & $(4)$ & $(3,698)$ \\
\hline \multicolumn{4}{|l|}{ Employment status (ref.: permanent contract) } \\
\hline Temporary contract (FTC or TAW) & -0.0171 & $20.20 * * *$ & 18,366 \\
\hline Unemployed & $0.537^{* * *}$ & (4) & $(3,698)$ \\
\hline \multicolumn{4}{|l|}{ Class Position (Ref.: higher grade prof.) } \\
\hline Lower grade professionals & $1.196 *$ & & \\
\hline Routine non-manuals, higher grade & $1.185^{* *}$ & & \\
\hline Routine non-manuals, lower grade & $1.497 * * *$ & $17.21^{+}$ & 9,907 \\
\hline Lower grade techn., skilled manuals & $1.085^{* *}$ & $(10)$ & $(1,996)$ \\
\hline Semi-/unskilled manual \& farm workers & $1.22 * *$ & & \\
\hline Industry-specific share of new FTCs & -0.024 & - & $\begin{array}{c}9,767 \\
(1,968)\end{array}$ \\
\hline Local unemployment rate & 0.0186 & - & $\begin{array}{l}18,366 \\
(3,698)\end{array}$ \\
\hline Household income $^{b}$ & $-0.519 * * *$ & - & $\begin{array}{l}18,366 \\
(3,698)\end{array}$ \\
\hline Female respondent & $0.210+$ & & $\begin{array}{l}18,366 \\
(3,698)\end{array}$ \\
\hline \multicolumn{4}{|l|}{ Family status } \\
\hline \multicolumn{4}{|l|}{ Men (ref.: single) } \\
\hline Partner, unemployed & -0.171 & $9.87^{*}$ & 6,828 \\
\hline Partner, employed & $-0.649 *$ & $(4)$ & $(1,375)$ \\
\hline \multicolumn{4}{|l|}{ Women (ref.: single) } \\
\hline Partner, unemployed & 0.463 & 2.56 & 6,009 \\
\hline Partner, employed & 0.0402 & $(4)$ & $(1,210)$ \\
\hline
\end{tabular}

Note: ${ }^{a}$ The null hypothesis states that jointly adding these interactions to the base model (Model I, Table 1), does not improve the goodness of fit. ${ }^{b}$ Equivalised according to OECD scale, rounded to 100 euros and logarithmized.

${ }^{* * *} p<0.001,{ }^{*} p<0.01,{ }^{*} p<0.05,+p<0.1$.

sented in the vignettes by the gain of household income (see online appendix). Table 3 shows the point estimates and $95 \%$ CIs by educational level and employment status. Estimations in the left columns of Table 3 refer to the principal decision to consider a fixed-term job offer at all (tier 1 of the craggit models), which is a much more fundamental decision stage than the fine-tuning taking place on tier 2. According to these estimates, the gain of household income associated with a 1-year contract would have to exceed the gain of household income associated with a permanent contract by 33 percentage points on average, so that a 1-year contract is considered as favorable as a permanent one. Most important, the estimates again illustrate the sub- stantially higher bargaining power of higher educated and permanently employed individuals: respondents with tertiary education (CASMIN_high) would consider a 1-year contract with the same probability as a permanent one only in case it offered a gain of household income that is higher by 57 percentage points. For permanent workers to be indifferent between a 1-year and a permanent contract the gain of household income associated with a 1-year contract would have to exceed the gain of household income associated with a permanent contract by 42 percentage points. The monetary compensations requested by other groups are substantially lower but throughout above an increase by 20 percentage points (point estimates). 
a) Men

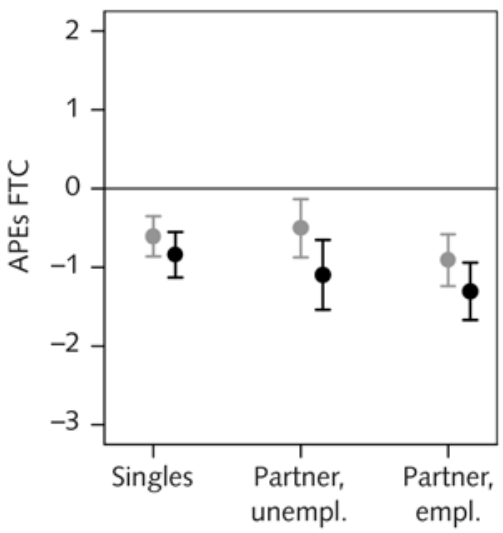

Partnership Status

3-year FTC $\bullet$ 1-year FTC b) Women

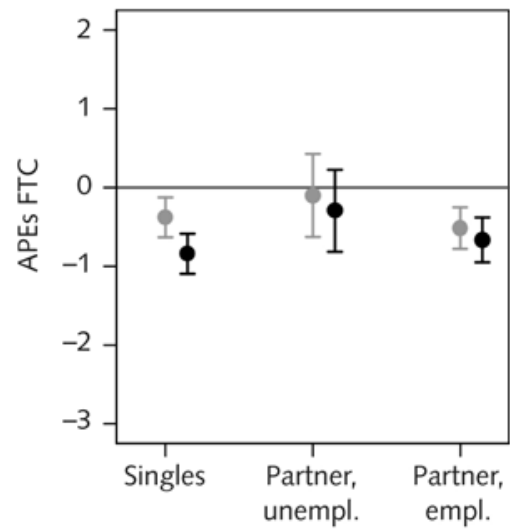

Partnership Status

- 3-year FTC • 1-year FTC

Note: APEs from craggit models estimated separately for respondents with different gender or family status. All estimates are based on at least $n=823$ evaluations of job offers.

Fig. 4 APEs of FTCs by Gender and Family Status with $95 \% \mathrm{Cls}$

Table 3 Monetary Compensation (Additional Gain of Household Income) Needed for Considering 1-Year Instead of Permanent Contract (Percentage Points)

\begin{tabular}{|c|c|c|c|c|c|c|}
\hline & \multicolumn{3}{|c|}{ Probit (Tier 1) } & \multicolumn{3}{|c|}{ OLS (Tier 1 + 2) } \\
\hline & \multirow{2}{*}{ Point estimate } & \multicolumn{2}{|c|}{$95 \% \mathrm{Cl}$} & \multirow{2}{*}{ Point estimate } & \multicolumn{2}{|c|}{$95 \% \mathrm{Cl}$} \\
\hline & & lower & upper & & lower & upper \\
\hline Overall & 32.79 & 25.82 & 39.77 & 32.51 & 25.56 & 39.47 \\
\hline \multicolumn{7}{|l|}{ Education } \\
\hline CASMIN_low & 34.44 & 18.28 & 50.61 & 33.67 & 17.81 & 49.53 \\
\hline CASMIN_medium & 27.86 & 20.03 & 35.69 & 27.69 & 19.85 & 35.52 \\
\hline CASMIN_high & 57.31 & 29.42 & 85.20 & 57.40 & 28.55 & 86.24 \\
\hline \multicolumn{7}{|l|}{ Employment status } \\
\hline Employed, permanent contract & 41.82 & 30.03 & 53.61 & 41.71 & 29.81 & 53.61 \\
\hline Employed, temporary contract & 37.81 & 18.81 & 56.82 & 37.85 & 18.50 & 57.19 \\
\hline Unemployed & 22.59 & 13.20 & 31.97 & 22.33 & 13.04 & 31.63 \\
\hline
\end{tabular}

Note:All estimates are based on the Stata ado 'wtp' (Hole 2007). The probit model only refers to the decision to consider a job offer at all ( $y=0$ versus $y>0$; which is equivalent to the estimates of tier 1 of the craggit model), while the OLS model considers all possible values of the dependent variable (i. e. both decision stages).

Similar results are found when estimating compensations not only for tier 1 but by using the complete distribution of the dependent variable (i. e. using as dependent variable not only a binary indicator of willingness to accept the offer being larger than zero or not but the original quantitative measurement on the 11-point rating scale). These estimates are shown in the right-hand columns of Table 3. They are based on an OLS regression because, to the best of our knowledge, for the craggit model no techniques exist that allow estimating standard errors for cross-elasticities summarizing the tiers. ${ }^{21}$

21 Both craggit and OLS models yield very similar estimates (Table A2.4, online appendix). The similarity of results for monetary compensations shown in Table 3 again proves the robustness of results with respect to the statistical model; in addition, the similarity of OLS estimates with estimates of tier 1 of the craggit model underlines the importance of the first decision stage (tier 1). 
Interestingly, all results on the monetary compensations again illustrate that FTCs are predominantly regarded as very unfavorable working conditions. Moreover, they demonstrate the high relevance of this job feature for explaining labor market inequalities also in other domains of labor market research, e.g., in investigating the chances of getting workers contracted.

\section{Discussion}

The widespread use of FTCs yielded a large literature on employers' motives to offer FTCs, while workers' rationales behind accepting fixed-term jobs received much less attention. In this article, for the first time an experimental approach was used to estimate workers' willingness to accept fixedterm jobs. Provided that nearly all workers prefer permanent contracts, the willingness to accept FTCs can be regarded as an indicator of the extent to which individuals' relative bargaining power is shaped by social factors (like social class or education), as predicted by modern class and bargaining theories.

First of all, results clearly demonstrate workers' preference for permanent over fixed-term contracts when confronted with jobs of otherwise comparable quality. Doing so, the experimental design complements existing studies in an important way: By assessing workers' willingness to accept FTCs while controlling for possible compensations, selectivity and other types of bias caused by unobserved characteristics are avoided. Thus it is possible to disentangle workers' assessment of different contract types from evaluations of further job characteristics, which might represent compensations for FTCs that are only paid to individuals with higher bargaining power.

Second, the study reveals social inequalities regarding the risk of precarious employment. Workers' willingness to make concessions with regard to job security is shaped by factors defining their bargaining position vis-à-vis employers. Higher qualifications, a higher social class position, and a better financial standing all have a strong negative impact on the reported likelihood of accepting fixed-term jobs, while unemployment fosters the propensity to accept FTCs. Effects of labor market integration and economic resources are also manifest in the level of financial compensation required for precarious contracts. Individuals in weak bargaining positions, notably low qualified or unemployed persons, tend to be more willing to accept fixed-term jobs.
Finally, evidence with regard to the impact of labor market context and family background is less clear cut. For the local unemployment rate and the industry-specific share of FTCs no significant effects could be detected; a reduced willingness to accept FTCs in case of living with an employed partner was found only for men. Even when controlling for qualifications and class positions, women tend to be more willing to accept FTCs than men.

To sum up, results suggest that labor market inequalities are clearly shaped by social positions that reflect specific power imbalances between employers and employees. Most factors that were tested in this paper showed that individuals in disadvantaged labor market positions have a high propensity of accepting FTCs and thus a higher risk of further weakening their bargaining position.

\section{Conclusion}

Previous studies showed FTCs to be widespread among both low-skilled and high-skilled workers (Gebel \& Giesecke 2009). The evidence presented here nevertheless reveals differences regarding workers' attitudes towards FTCs. Unskilled or unemployed individuals are less likely to oppose insecure jobs, while high-skilled workers' bargaining power allows them to be pickier about job offers: their willingness to accept FTCs is on average lower and also contingent on better financial trade-offs. Not measuring these higher financial trade-offs or other forms of compensations might lead to the misleading conclusion that employment risks have become largely individualized. Our findings, on the contrary, suggest the existence of path-dependencies through which social inequalities tend to reinforce themselves.

The interpretation of family background effects is less straightforward. While the pattern found for male respondents might be interpreted in terms of a decommodifying effect of living with a second earner, the fact that family status has no impact for women requires explanation. There might be two different forces cancelling each other out: the bargaining power that is gained by a decommodifying effect of another earner and the bargaining power that is lost due to the fact of women being more likely the second earner (Blossfeld et al. 2001), which reduces flexibility in regard to working hours or (geographical) workplaces. However, more research is needed to disentangle these factors and to explain the overall tendency of women to be more willing to accept FTCs, regardless of their family status. More 
generally, the findings illustrate that gender inequalities in employment are not only manifest in income inequalities but also in a gender-specific willingness to accept unfavorable working conditions.

Notwithstanding its merits, the methodology of this study has certain limitations. First of all, the experimental design only allowed measuring behavioral intentions. It might be objected that these intentions do not allow conclusions on real behavior. One reason would be the social desirability bias in reporting them. The indirect evaluation task in factorial surveys with many experimental factors varying at the same time is, however, regarded as being much more immune against this bias than standard item questions (Mutz 2011). Moreover, the theory of planned behavior suggests behavioral intentions will have strong predictive power with respect to behavior, with most discrepancies being caused by additional information or (job) options that were not yet available in initial planning stages (e. g., Ajzen 1991). Put differently, the causal impact of factors is likely found to be very similar between measures of intentions and real behavior (see also Nisic \& Auspurg 2009). ${ }^{22}$

There might be additional factors that are relevant in real decisions, but as long as these do not interact with the factors under study, one can still achieve a valid measurement of their causal impact (Aronson et al. 1998; Brewer 2000). Our design deliberately focused on a limited number of decision factors. Future research could expand on additional factors (such as further training options or firm-specific conversion rates of FTCs into permanent contracts) or trade-offs beyond financial compensation (such as the prospect of getting a subsequent permanent job). In this context, it would be particularly interesting to further investigate the role of commuting distance, which according to our study also has a very strong impact on job acceptance (for some results on the same data base: Abraham et al. 2013; Auspurg et al. 2014).

With respect to the sample of respondents, unemployed workers and low-income households were

\footnotetext{
22 Given that unemployed recipients of means-tested benefits are obliged to accept any job offers, social desirability might also have influenced their stated general acceptance of hypothetical job offers in this survey. Yet, even if their willingness to accept jobs was overestimated in absolute terms, this should not interfere with a reliable measurement of the causal impact of experimental factors. In particular, high internal validity is the strength of all experimental approaches including factorial survey methods (Auspurg \& Hinz 2015).
}

deliberately oversampled. Using a more representative sample would certainly change the descriptive results. ${ }^{23}$ We do not expect the results of hypotheses tests to change, as this would only be the case if relevant moderator variables were omitted (Auspurg \& Hinz 2015). This is, however, very unlikely as the respondent sample covers a very broad range of the general population. Oversampling unemployed workers leads to a higher variance in test variables (like the employment status) and hence to higher statistical power. Nevertheless, replicating the results with different respondent samples would be insightful. Validations should be based on samples with a comparably high variation in test variables and additional variables that might moderate the tests of hypotheses (i. e., further vignette dimensions or contexts that modify bargaining power, such as social security systems).

Concerning the economic context, the positive though non-significant - effect of the unemployment rate suggests that a high level of regional unemployment might weaken workers' power to avoid precarious jobs. Future research could use more sophisticated measures of the local opportunity structure. Local labor markets do not necessarily coincide with administrative units but are rather defined by traffic connections, commuting flows, and other forms of connections to metropolitan and industrial areas (Litzel \& Möller 2011). Similarly, an impact of the industry-specific FTC rate might be detected by using a more fine-grained industry measure than the one available for this study.

The enforceability of unfavorable working conditions is certainly also linked to the degree of collective bargaining power gained by labor unions and other forms of worker organizations, which were only roughly captured with sector variables. Currently, many sectors experience a fragmentation of the workforce (caused, for instance, by outsourcing core jobs to peripheral units) that weakens collective bargaining power (Holst 2014). Future research could study how changes in labor market relations interfere with the impact of individual bargaining power.

Focusing on Germany, in this study a conservative welfare state was observed in which the workforce still enjoys a comparatively high level of decommodification, e.g. in the form of unemployment benefits. In more liberal welfare states, like the UK or

\footnotetext{
${ }^{23}$ For instance, one can expect a higher willingness to accept offers that require a household move; see Abraham et al. 2013.
} 
US, even larger social inequalities in the distribution of bargaining power can be expected. Policy effects could be studied by comparative studies in the future.

To conclude, the empirical results suggest that the risk of having a fixed-term job is apparently not only determined by employers' hiring practices or flexibilization strategies. The potential to avoid insecure jobs is largely dependent on decommodifying factors reflecting individuals' bargaining power. From a social policy perspective, path dependencies between current and future labor market risks could be avoided by the provision of decommodifying resources. Previous studies have already shown that unemployment benefits and other welfare state transfers can reduce long-term scar effects of unemployment or precarious employment, as workers can afford longer job search periods and hence experience fewer constraints in regard to job choices (Gangl 2004). In the study at hand, this decommodifying effect of a higher household income was supported again. Similarly, as education seems to be an important aspect of bargaining power, better options for further training could offer steppingstones into permanent employment. Fixed-term workers, unemployed persons, and low-skilled workers have relatively low chances to get access to further training (Bellmann et al. 2013; Hubert \& Wolf 2003). Insofar as lower education implies less bargaining power, reduced access to further training yields a higher risk of remaining in insecure employment. The study deliberately focused on FTCs only, but there is evidence that other forms of nonstandard work (like part-time and marginal employment) provide even stronger path-dependencies in non-standard employment (for Germany, see Brülle 2013). As the risks of non-standard employment are strongly shaped by social factors, they deserve high awareness in political and social sciences.

\section{References}

Abraham, M., K. Auspurg, S. Bähr, C. Frodermann \& S. Gundert, 2013: Unemployment and Willingness to Accept Job Offers: Results of a Factorial Survey Experiment. Journal of Labour Market Research 46: 283305.

Abraham, M., K. Auspurg \& T. Hinz, 2010: Migration Decisions Within Dual-Earner Partnerships: A Test of Bargaining Theory. Journal of Marriage and Family 72: 876-892.

Addabbo, T. \& D. Favaro, 2012: Part-Time and Temporary Employment: A Gender Perspective. Pp. 53-78 in: T. Addabbo \& G. Solinas (eds.), Non-Standard Em- ployment and Quality of Work. The Case of Italy. Berlin: Physica.

Ajzen, I., 1991: The Theory of Planned Behavior. Organizational Behavior and Human Decision Processes 50: 179-211.

Aronson, E., T.D. Wilson \& M.B. Brewer, 1998: Experimentation in Social Psychology. Pp. 99-142 in: D.T. Gilbert, S.T. Fiske \& G. Lindzey (eds.), The Handbook of Social Psychology. New York: McGraw-Hill.

Auspurg, K., C. Frodermann \& T. Hinz, 2014: Berufliche Umzugsentscheidungen in Partnerschaften. Eine experimentelle Prüfung von Verhandlungstheorie, FrameSelektion und Low-Cost-These. Kölner Zeitschrift für Soziologie und Sozialpsychologie 66: 21-50.

Auspurg, K. \& T. Hinz, 2015: Factorial Survey Experiments. SAGE Series Quantitative Applications in the Social Sciences No. 175. Thousand Oaks: Sage.

Auspurg, K. \& T. Schönholzer, 2013: An Heim und Herd gebunden? Zum Einfluss von Pendelstrecken auf geschlechtsspezifische Lohnunterschiede. Zeitschrift für Soziologie 42: 138-156.

Baranowska, A., M. Gebel \& I.E. Kotowska, 2011: The Role of Fixed-Term Contracts at Labour Market Entry in Poland: Stepping-Stones, Screening Devices, Traps or Search Subsidies. Work, Employment and Society 25: 777-793.

Barbieri, G. \& P. Sestito, 2012: The Quality of Temporary Work. Pp. 79-104 in: T. Addabbo \& G. Solinas (eds.), Non-Standard Employment and Quality of Work. The Case of Italy. Berlin: Physica.

Beck, U., 1992: Risk Society: Towards a New Modernity. London: Sage.

Bellmann, L., P. Grunau, U. Leber \& M. Noack, 2013: Weiterbildung atypisch Beschäftigter. Gütersloh: Bertelsmann Stiftung.

Blau, P., 1964: Exchange and Power in Social Life. New York: Wiley.

Blossfeld, H.-.P, S. Drobnic \& G. Rohwer, 2001: Spouses' Employment Careers in (West) Germany. Pp. 53-76 in: H.-P. Blossfeld \& S. Drobnic (eds.), Careers of Couples in Contemporary Society. From Male Breadwinner to Dual-Earner Families. Oxford: Oxford University Press.

Brauns, H., S. Scherer \& S. Steinmann, 2003: The CASMIN Educational Classification in International Comparative Research. Pp. 221-244 in: J.H.P. HoffmeyerZlotnik \& C. Wolf (eds.), Advances in Cross-National Comparison. New York: Kluwer.

Breen, R., 1997: Risk, Recommodification and Stratification. Sociology 31: 473-489.

Brewer, M. B., 2000: Research Design and Issues of Validity. Pp. 3-16 in: H.T. Reis \& C.M. Judd (eds.), Handbook of Research Methods in Social and Personality Psychology. Cambridge: Cambridge University Press.

Brülle, J., 2013: Unterschiede in den Arbeitsmarktchancen von atypisch Beschäftigten: Effekte von Beschäftigungsformen oder Erwerbspräferenzen? Zeitschrift für Soziologie 42: 157-179.

Burke, W.J., 2009: Fitting and Interpreting Cragg's Tobit Alternative Using Stata. Stata Journal 9: 584-592. 
Cragg, J.G., 1971: Some Statistical Models for Limited Dependent Variables with Application to the Demand for Durable Goods. Econometrica 39: 829-844.

De Jong, J., N. De Cuyper, H. De Witte, I. Silla, \& C. Bernhard-Oettel, 2009: Motives for Accepting Temporary Employment: A Typology. International Journal of Manpower 30: 237-252.

Devine, T.J. \& N.M. Kiefer, 1991: Empirical Labor Economics: The Search Approach. Oxford: Oxford University Press.

Doeringer, P.B. \& M.J. Piore, 1971: Internal Labor Markets and Manpower Analysis. London: Lexington.

Eichhorst, W., P. Marx \& E. Thode, 2010: Atypische Beschäftigung und Niedriglohnarbeit. Benchmarking Deutschland: Befristete und geringfügige Tätigkeiten, Zeitarbeit und Niedriglohnbeschäftigung. Gütersloh: Bertelsmann.

Emerson, R.M., 1962: Power-Dependence Relations. American Sociological Review 27: 692-703.

Erikson, R. \& J.H. Goldthorpe, 1992: The Constant Flux. A Study of Class Mobility in Industrial Societies. Oxford: Clarendon.

Frodermann, C., K. Auspurg, T. Hinz, S. Bähr, M. Abraham, S. Gundert \& A. Bethmann, 2013: Das faktorielle Survey-Modul zur Stellenannahmebereitschaft im PASS, 5. Erhebungswelle (2011). FDZ-Methodenbericht 05/2013. Nuremberg: Institute for Employment Research (IAB).

Gangl, M., 2004: Welfare States and the Scar Effects of Unemployment: A Comparative Analysis of the United States and West Germany. American Journal of Sociology 109: 1319-1364.

Gash, V., 2008: Bridge or Trap? Temporary Workers' Transitions to Unemployment and to the Standard Employment Contract. European Sociological Review 24: 651-668.

Gash, V., A. Mertens \& L. Romeu Gordo, 2007: Are Fixed-Term Jobs Bad for Your Health? A Comparison of West-Germany and Spain. European Societies 9: 429-458.

Gebel, M. \& J. Giesecke, 2009: Labour Market Flexibility and Inequality: The Changing Risk Patterns of Temporary Employment in West Germany. Journal for Labour Market Research 42: 234-251.

Gebel, M. \& J. Giesecke, 2011: Labor Market Flexibility and Inequality: The Changing Skill-Based Temporary Employment and Unemployment Risks in Europe. Social Forces 90: 17-40.

Giesecke, J., 2009: Socio-Economic Risks of Atypical Employment Relationships: Evidence from the German Labour Market. European Sociological Review 25: 629-646.

Giesecke, J. \& M. Groß, 2003: Temporary Employment: Chance or Risk? European Sociological Review 19: 161-177.

Gundert, S., 2007: Befristete Beschäftigung bei Berufsanfängern und älteren Arbeitnehmern. Berlin: Logos.

Gundert, S. \& C. Hohendanner, 2014: Do Fixed-term and Temporary Agency Workers Feel Socially Excluded? Labour Market Integration and Social Well-being in Germany. Acta Sociologica 57: 135-152.
Hagen, T., 2002: Do Temporary Workers Receive Risk Premiums? Assessing the Wage Effects of Fixed-term Contracts in West Germany by a Matching Estimator Compared with Parametric Approaches. LABOUR: Review of Labour Economics and Industrial Relations 16: 667-705.

Hohendanner, C., 2012: Befristete Arbeitsverhältnisse: Auch Mann trägt kurz. IAB-Forum 1: 62-67.

Hohendanner, C., 2013: Befristet Beschäftigte werden häufiger übernommen. Press Release. June 20, 2013. Nuremberg: IAB.

Holst, H., 2014: 'Commodifying Institutions': Vertical Disintegration and Institutional Change in German Labour Relations. Work, Employment and Society 28: 320.

Hubert, T. \& C. Wolf, 2007: Determinanten der beruflichen Weiterbildung Erwerbstätiger. Empirische Analysen auf der Basis des Mikrozensus. Zeitschrift für Soziologie 36: 473-493.

Jahoda, M., 1981: Work, Employment, and Unemployment - Values, Theories, and Approaches in Social Research. American Psychologist 36: 184-191.

Jasso, G., 2006: Factorial Survey Methods for Studying Beliefs and Judgments. Sociological Methods and Research 34: 334-423.

Kurz, K., 2002: Fixed-term Contracts and Unemployment at the Beginning of the Employment Career in Germany: Does Gender Matter? Pp. 133-157 in: E. Ruspini \& A. Dale (eds.), The Gender Dimension of Social Change. The Contribution of Dynamic Research to the Study of Women's Life Courses. Bristol: Policy.

Litzel, N. \& J. Möller, 2011: Industrial Clusters and Economic Integration: Theoretic Concepts and an Application to the European Metropolitan Region Nuremberg. Pp. 262-295 in: M. Jovanovic (ed.), International Handbook on the Economics of Integration, Volume II: Competition, Spatial Location of Economic Activity and Financial Issues. Cheltenham: Elgar.

Manning, A., 2003: Monopsony in Motion. Imperfect Competition in Labor Markets. Princeton: Princeton University Press.

McGinnity F, A. Mertens \& S. Gundert S, 2005: A Bad Start? Fixed-term Contracts and the Transition from Education to Work in West Germany. European Sociological Review 21: 359-374.

Mertens, A. \& F. McGinnity, 2005: A “Two-Tier” Labour Market for Fixed-term Jobs? Evaluating Evidence from West Germany Using Quantile Regression. Schmollers Jahrbuch 125: 75-85.

Mincer, J., 1978: Family Migration Decisions. Journal of Political Economy 86: 749-773.

Mutz, D., 2011: Population-Based Survey Experiments. Princeton: Princeton University Press.

Nisic, N. \& K. Auspurg, 2009: Faktorieller Survey und klassische Bevölkerungsumfrage im Vergleich: Validität, Grenzen und Möglichkeiten beider Ansätze. Pp. 262-295 in: P. Kriwy \& C. Gross (eds.), Klein aber fein! Quantitative empirische Sozialforschung mit kleinen Fallzahlen. Wiesbaden: VS.

OECD, 2012: Employment Outlook. Paris: OECD. 
Ortiz, L., 2010: Not the Right Job, but a Secure One: Over-Education and Temporary Employment in France, Italy and Spain. Work, Employment and Society 24: 47-64.

Picchio, M., 2012: The Dynamics of Unemployment, Temporary and Permanent Employment in Italy. Pp. 127-148 in: T. Addabbo \& G. Solinas (eds.), NonStandard Employment and Quality of Work. The Case of Italy. Berlin: Physica.

Regini, M., 2000: Between Deregulation and Social Pacts: The Responses of European Economies to Globalization. Politics and Society 28: 5-33.

Rogers, W.H., 1993: Regression Standard Errors in Clustered Samples. Stata Technical Bulletin 3: 19-23.

Rossi, P.H. \& A.B. Anderso, 1982: The Factorial Survey Approach: An Introduction. Pp. 15-67 in: P.H. Rossi \& S. L. Nock (eds.), Measuring Social Judgments: The Factorial Survey Approach. Beverly Hills: Sage.

Spence M.,1973: Job Market Signaling. Quarterly Journal of Economics 87: 355-374.

Stiglitz, J.E.,1975: The Theory of "Screening”, Education, and the Distribution of Income. American Economic Review 65: 283-300.

Strandh, M., 2000: Different Exit Routes from Unemploy- ment and their Impact on Mental Well-Being: The Role of the Economic Situation and the Predictability of the Life Course. Work, Employment and Society 14: 459479.

Tan, H.-H. \& C.-P. Tan, 2002: Temporary Employees in Singapore: What Drives Them? Journal of Psychology 136: 83-102.

Trappmann, M., J. Beste, A. Bethmann \& G. Müller, 2013: The PASS Panel Survey after Six Waves. Journal for Labour Market Research 46: 275-281.

Wallander, L., 2009: 25 Years of Factorial Surveys in Sociology: A Review. Social Science Research 38: 505-520.

Walwei, U., 2013: Times of Change: What Drives the Growth of Work Arrangements in Germany? Journal for Labour Market Research, Online First.

Wingerter, C., 2011: Employment Increase in 2010 Largely Due to Temporary Work. Press Release No. 270. July 19, 2011. Wiesbaden: Federal Statistical Office.

Wright, E.O., 1997: Class Counts. Comparative Studies in Class Analysis. Cambridge: Cambridge University Press.

Wooldridge, J.M., 2010: Econometric Analysis of Cross Section and Panel Data. Cambridge, Mass.: MIT Press.

\section{Autorenvorstellung}

Katrin Auspurg, geb. 1974 in München. Studium der Sozialen Arbeit an der Fachhochschule München sowie der Soziologie, Statistik und Sozialpsychologie an der Ludwig-Maximilians-Universität München. Promotion an der Universität Konstanz. Von 2006 bis 2013 Wissenschaftliche Mitarbeiterin und Akademische Rätin am Fachbereich Soziologie der Universität Konstanz. Seit 2014 Professorin für empirische Sozialforschung an der Goethe-Universität Frankfurt.

Forschungsschwerpunkte: Methoden der empirischen Sozialforschung, soziale Ungleichheit, Familien- und Bildungssoziologie, analytische Soziologie.

Wichtigste Publikationen: Factorial Survey Experiments (mit Thomas Hinz), Thousand Oaks 2015; Migration Decisions Within Dual-Earner Partnerships: A Test of Bargaining Theory (mit M. Abraham \& T. Hinz), Journal of Marriage and Family 2010; zuletzt in dieser Zeitschrift: An Heim und Herd gebunden? Zum Einfluss von Pendelstrecken auf geschlechtsspezifische Lohnunterschiede (mit T. Schönholzer), ZfS 42, 2013: 138-156.

Stefanie Gundert, geb. 1978 in Koblenz. Studium der Sozialwissenschaften an der Gerhard-Mercator-Universität Wuppertal und der Universität Essen-Duisburg. Von 2003-2006 Promotionsstipendiatin des Max-Planck-Instituts für Bildungsforschung, Berlin. Promotion an der Freien Universität Berlin, anschließend Post-Doc-Aufenthalt am Center for Research on Inequalities and the Life Course (CIQLE) der Yale University. Seit 2009 wissenschaftliche Mitarbeiterin am Institut für Arbeitsmarkt- und Berufsforschung (IAB), Nürnberg.

Forschungsschwerpunkte: Qualität der Beschäftigung, Arbeitsmarktflexibilisierung, atypische Beschäftigung, soziale Ungleichheit, Lebenslaufforschung.

Wichtigste Publikationen: Befristete Beschäftigung bei Berufsanfängern und älteren Arbeitnehmern, Berlin 2007; Gender Segregation in Training and Social Mobility of Women in West Germany (mit K.U. Mayer), European Sociological Review 2012; Do Fixed-term and Temporary Agency Workers Feel Socially Excluded? Labour Market Integration and Social Well-being in Germany (mit C. Hohendanner), Acta Sociologica 2014. 